\title{
Meat quality attributes of night-cropped Impala (Aepyceros melampus)
}

\section{L.C. Hoffman ${ }^{\#}$}

Department of Animal Sciences, University of Stellenbosch, P Bag X1, Matieland, 7602. South Africa.

\begin{abstract}
The aim of this experiment was to determine the effect of using a heavy or a light calibre rifle for night cropping of impala (Aepyceros melampus) on meat quality ( $\mathrm{pH}$, colour, cooking and drip loss, tenderness). The effect of gender on these parameters was also tested. Eight male and eight female impala were shot at night using either a heavy or a light calibre rifle. Sex and rifle calibre had an effect on some of the parameters tested. An exponential function $\left(\mathrm{y}=\mathrm{a}+\mathrm{b} \mathrm{e}^{(\mathrm{ct})}\right)$ was fitted to the rate of $\mathrm{pH}$ decline with time. Constants for females were: $\mathrm{a}=$ $5.667 \pm 0.0142, \mathrm{~b}=2.097 \pm 0.1777$ and $\mathrm{c}=-0.451 \pm 0.0541$, and constants for males were: $\mathrm{a}=5.792 \pm 0.0142, \mathrm{~b}=$ $3.055 \pm 0.1777$ and $\mathrm{c}=-0.711 \pm 0.0541$. These constants differed $(\mathrm{P}<0.05)$ between sexes. The impala showed a mean $\mathrm{pH}_{45}$ of $7.17 \pm 0.0674$ and a mean $\mathrm{pH}_{\mathrm{f}}$ of $5.70 \pm 0.068$. Mean drip and cooking loses were $2.55 \pm 0.300 \%$, $23.98 \pm 0.367 \%$, respectively, whilst a mean shear value of $3.65 \pm 0.293 \mathrm{~kg} / 1.27 \mathrm{~cm}$ diameter was also noted. The darker colour of venison was reflected in the CIELAB values of the M. longissimus thoracis $\left(\mathrm{L}^{*}=29.22 \pm 0.590\right.$, $a^{*}=11.26 \pm 0.319, b^{*}=7.36 \pm 0.266$ ). One of the animals was stressed prior to and during killing, and showed attributes associated with ante-mortem stress: higher $\mathrm{pH}_{\mathrm{f}}$, lower drip loss and darker meat. The results indicate that the present method of cropping ungulates does not have a negative effect on the meat quality parameters tested.
\end{abstract}

Keywords: muscle $\mathrm{pH}$, game meat, stress, cropping, impala, drip loss, rifle calibre

${ }^{\#}$ E-mail: $\underline{\text { lch@land.sun.ac.za }}$

\section{Introduction}

Traditionally, hunters prefer to shoot animals through the shoulder (hitting either the heart or, more commonly, the lungs) rather than through the neck or head. The shoulder shot can result in up to $20 \%$ of the carcass being damaged by the bullet, whilst a shot through the neck results in minimum (3\%) wastage (von La Chevallerie \& van Zyl, 1971). Heart shots are also likely to result in a higher incidence of wounding and do not instantly render the animals insensible (Lewis et al., 1997). In the meat trade, the neck is also classified as a cut of less value than the shoulder.

Within South Africa the commercial cropping of wild ungulates consists of shooting the animals either from a helicopter or from a hide during the day, or night shooting. Veary (1991), Lewis et al. (1997) and Hoffman \& Ferreria (2000) have shown night shooting to be the best methodology for the harvesting of game. It not only causes the least damage and wastage to the carcass but it also exerts the least stress on the survivors. A head or neck shot normally results in the animals dropping instantly, whilst a shoulder or rib shot could result in the animals running substantial distances before dying (von La Chevallerie \& van Zyl, 1971). The latter is unacceptable from a meat quality perspective (Gregory, 1996; Issanchou, 1996).

Apart from the work of Veary (1991) and von La Chevallerie \& van Zyl (1971), little data could be found on the effects of shooting on the meat quality of wild ungulates. These two reports indicate that the level of antemortem stress may be detrimental to meat quality (colour and water binding capacity). Within South Africa, venison is normally perceived to be a dark unattractive red colour, somewhat similar to beef that has been classified as dark firm and dry (DFD) (Scanga et al., 1998). This phenomenon is normally associated with ante-mortem stress which causes muscle glycogen depletion and thus increases the risk of a high ultimate pH (Gregory, 1996; Scanga et al., 1998) and therefore the likelihood of the meat spoiling, pathogens proliferating and of the meat being unacceptably dark in colour (Gill \& Reichel, 1989).

In this investigation, the effect of using a heavy or a light calibre rifle on the meat quality $(\mathrm{pH}$, colour, cooking and drip loss, tenderness) of night cropped impala (Aepyceros melampus) was examined. The effect of gender on these parameters was also tested.

\section{Material and Methods}

Impala were sampled from the Maneze Wildlife Conservancy in central Zimbabwe. Eight male and eight female impala were harvested at night using spotlights in a procedure similar to that described by Lewis et al. (1997). Two rifles, a heavy $7.9 \mathrm{~mm}$ calibre and a light $0.22 \mathrm{~mm}$ calibre were used. The shooting order of the different rifles was randomized. The dead animals were weighed within minutes after shooting, suspended by their 
back legs and exsanguinated by cutting the throat with a sharp knife. After the targeted number of antelopes had been harvested (over a $3 \mathrm{hr}$ period) the animals were transported to a commercial abattoir where they were further processed according to standard South African and Zimbabwean practices. This consisted of skinning, evisceration, cleaning of carcasses (Hoffman, 2000).

The $\mathrm{pH}$ was measured at the following periods after shooting: 45 mins $\left(\mathrm{pH}_{45}\right), 2,4,6 \mathrm{~h}$. Thereafter four additional readings corresponding to $8,15,21$ and $36 \mathrm{hrs}\left(\mathrm{pH}_{\mathrm{f}}\right)$ post mortem were taken. The latter readings were taken at fixed times, and were correspondingly earlier for animals cropped during the last hours of the shoot. The $\mathrm{pH}$ was measured in the hindquarters in the M. semitendinosus using a calibrated (standard buffers at $\mathrm{pH} 4.0$ and 7.0) Crison 506 portable $\mathrm{pH}$ meter. The carcasses were placed in a cooler $\left(0.8^{\circ} \mathrm{C}\right)$ five to eight hours after cropping (depending on the time at which the animals were shot), where the remaining measurements were taken.

Thirty-six hours after cropping, two loin sub-samples (the first taken at the first lumbar vertebrae and the second, caudally adjacent to it) were taken for determination of drip and cooking losses (Honikel, 1998). Cooking loss was determined by placing weighed samples of approximately $100 \mathrm{~g}$, sealed in plastic bags, in water at $75^{\circ} \mathrm{C}$ for 50 minutes. This allowed for sufficient heat penetration without causing excessive denaturation of collagen present in the meat. The bagged samples were allowed to cool to $25^{\circ} \mathrm{C}$ in running water. Weights of the cooked samples were determined after decanting the liquid phase, and the cooking loss calculated as total fluid lost, expressed as a percentage of the fresh (uncooked) sample. Five $1.27 \mathrm{~cm}$ diameter samples (from the centre of each M. longissimus thoracis sample) were removed at random for determining Warner-Bratzler shear force values (Voisey, 1976). The samples were cut parallel to the muscle fibre direction in order to measure the influence of the myofibrillar proteins on shear force. Maximum shear force values $(\mathrm{kg} / 1.27 \mathrm{~cm}$ diameter) were recorded for each sample (repeated five times) and a mean was calculated for each individual animal. The colour of the $M$. longissimus thoracis was also evaluated using a Color-guide $45^{\circ} / 0^{\circ}$ colorimeter (BYK-Gardner, USA) to determine $\mathrm{L}^{*}, \mathrm{a}^{*}$ and $\mathrm{b}^{*}$ values (Commission International de l' Eclairage, 1976), with $\mathrm{L}^{*}$ indicating brightness, $\mathrm{a}^{*}$ the redgreen range and $b^{*}$ the blue-yellow range.

The non-linear regression procedure (Proc NLIN) of SAS (1988) was used to fit regression models to the rate of $\mathrm{pH}$ decline over time. The model fitted was of the form $\mathrm{y}=\mathrm{a}+\mathrm{b} \mathrm{e}^{(\mathrm{ct})}$, where $\mathrm{y}$ is the dependant variable $(\mathrm{pH})$ and $t$ the time $(h)$. Thereafter, analyses of variance were performed on all the variables measured $(\mathrm{a}, \mathrm{b}$ and $\mathrm{c}$ values from the above mentioned model, as well as on shear values, drip and cooking losses and colour values) using the General Linear Models (GLM) procedure of SAS. The following model was fitted for main effects (sex, rifle calibre), as well as interactions:

$Y_{i j}=\mu+R_{i}+S_{j}+R S_{i j}+e_{i j}$

where $Y_{i j}$ is the dependent variable $(\mathrm{pH}), \mu=$ the overall mean, $R_{i}=$ the $i^{\text {th }}$ rifle calibre effect, $S_{j}=$ the $j^{\text {th }}$ sex effect, $\mathrm{RS}_{\mathrm{ij}}=$ the interaction between rifle calibre and sex and $\mathrm{e}_{\mathrm{ij}}=$ the residual error.

The differences between rifle calibre and sexes were, where appropriate, tested separately by means of the null hypothesis $\left(\mathrm{H}_{\mathrm{O}}\right)$, with $\mathrm{H}_{\mathrm{O}}: \mu=\mu_{\mathrm{O}}$ and the alternate hypothesis $\left(\mathrm{H}_{\mathrm{a}}\right)$ being $\mathrm{H}_{\mathrm{a}}: \mu \neq \mu_{\mathrm{O}}$. This was done by means of contrast analyses and estimated least square means $( \pm$ s.e.) as reported in the various tables. Differences between the variables were accepted as being significant if the probability of rejection of $\mathrm{H}_{\mathrm{O}}$ was less than $5 \%(\mathrm{P}<0.05)$ for rifle calibre and sex.

\section{Results and discussion}

The cropping method employed was effective and the percentage wounded (one animal was shot by the 0.22 through the ear) and missed shots were also similar to that noted by Lewis et al. (1997) and are within expected cropping limits. Fourteen of the animals were shot in the head, the remaining two were shot through the throat (and spinal coloumn) just below the jaw line. No meat was discarded from any of the animals because of bullet damage. All shot animals (with the exception of one male - see later) dropped immediately.

The heavier calibre rifle resulted in a statistically higher initial muscle $\mathrm{pH}$ and a faster rate of $\mathrm{pH}$ decline (Table 1) than the lighter calibre. Also, the use of the heavier calibre rifle nearly always resulted in the impala herd becoming alarmed and fleeing. This is unacceptable in any cropping operation where larger numbers of animals are removed within a herd over a very short time span (Lewis et al., 1997). 
Table 1 Least square mean values $( \pm \mathrm{se}$ ) for the constants $\mathrm{a}, \mathrm{b}$ and $\mathrm{c}$ of the exponential equation describing the change in $\mathrm{pH}$ with time for cropped impala.

\begin{tabular}{lccc}
\hline Main effect & \multicolumn{3}{c}{$\begin{array}{c}\text { Constants for the exponential equation: } \\
\text { y }=\mathrm{a}+\mathrm{b} \mathrm{e}^{(\mathrm{ct})}\end{array}$} \\
\cline { 2 - 4 } & $\mathrm{a}$ & $\mathrm{b}$ & $\mathrm{c}$ \\
\hline Sex & $5.667^{\mathrm{a}} \pm 0.0142$ & $2.097^{\mathrm{a}} \pm 0.1777$ & $-0.451^{\mathrm{a}} \pm 0.0541$ \\
Female & $5.792^{\mathrm{b}} \pm 0.0142$ & $3.055^{\mathrm{b}} \pm 0.1777$ & $-0.711^{\mathrm{b}} \pm 0.0541$ \\
Male & & & \\
Rifle calibre (mm) & $5.740 \pm 0.0162$ & $2.117^{\mathrm{a}} \pm 0.1790$ & $-0.477^{\mathrm{a}} \pm 0.0550$ \\
0.22 & $5.720 \pm 0.0162$ & $3.034^{\mathrm{b}} \pm 0.1790$ & $-0.686^{\mathrm{b}} \pm 0.0550$ \\
7.9 &
\end{tabular}

${ }^{\mathrm{ab}}$ Column means within main effects with the same superscript do not differ $(\mathrm{P}>0.05)$

Table 2 Meat quality parameters (mean \pm se) for male and female impala cropped at night.

\begin{tabular}{llll}
\hline Parameter & Female & Male & Probability $>\mathrm{t}$ \\
\hline $\mathrm{pH}_{45}$ & $7.05 \pm 0.105$ & $7.30 \pm 0.063$ & 0.0281 \\
$\mathrm{pH}_{\mathrm{f}}$ & $5.70 \pm 0.068$ & $5.82 \pm 0.129$ & 0.0404 \\
Drip loss (\%) & $2.66 \pm 1.097$ & $2.45 \pm 1.362$ & 0.7392 \\
Cooking loss (\%) & $23.48 \pm 1.449$ & $24.48 \pm 1.388$ & 0.1796 \\
Toughness (kg/1.27 cm & $3.21 \pm 0.236$ & $4.08 \pm 0.509$ & 0.1449 \\
diameter) & & & \\
$\mathrm{L}^{*}$ & $29.66 \pm 2.745$ & $28.78 \pm 1.985$ & 0.4715 \\
$\mathrm{a}^{*}$ & $11.42 \pm 0.960$ & $11.11 \pm 1.882$ & 0.6376 \\
$\mathrm{~b}^{*}$ & $7.62 \pm 0.759$ & $7.10 \pm 1.300$ & 0.3441 \\
\hline
\end{tabular}

"The colour of the M. longissimus thoracis was evaluated in terms of $\mathrm{L}^{*}, \mathrm{a}^{*}$ and $\mathrm{b}^{*}$ values (Commission International de l' Eclairage, 1976), with L* indicating brightness, $a^{*}$ the red-green range and $b^{*}$ the blue-yellow range.

Gender had an effect on the $\mathrm{pH}_{45}(\mathrm{P}<0.05)$, with the males having a higher mean $\mathrm{pH}_{45}($ Table 2$)$. For $\mathrm{pH}_{\mathrm{f}}$, the males still had a higher $(\mathrm{P}<0.05)$ mean value $(5.82)$ than the females $(5.70)$. These differences could be attributed to the more active response exhibited by males to any disturbance (Lewis et al., 1997). The males had also just finished their rutting season and were thus in a more excitable state (as noted from daytime observations) than what they would normally be in during the late winter season.

Both the sex of the animals and the rifle used had an effect $(\mathrm{p}<0.05)$ on the values of the constants $\mathrm{a}, \mathrm{b}$ and $\mathrm{c}$ derived from the non-linear equation fitted to the $\mathrm{pH}$ data. There was no sex by rifle interaction. The values of a, $\mathrm{b}$ and $\mathrm{c}$ are shown for the means of the two treatments (sex and rifle) in Table 1. Although the constants of the nonlinear regressions fitted the data, care must be taken in the interpretation of these values because the calculated $\mathrm{pH}$ of the meat in some of these exponential equations is above $8(\mathrm{t}=0)$, an improbable value.

The $\mathrm{pH}_{45}$ values depicted in Table 2 give a better indication of the naturally occurring $\mathrm{pH}_{0}( \pm 7.17)$ in impala muscle. The exponential equations do give a good prediction of the final asymptotic $\mathrm{pH}$ value $(<5.8)$ of the meat (Table 1 and 2). These values differ somewhat from those reported by Hoffman \& Ferreria (2000) on night cropping of Grey Duiker (Sylvicarpia grimmia) where a $\mathrm{pH}_{45}$ of 6.28 and $\mathrm{pH}_{24}$ of 5.55 with constants values of $\mathrm{a}=$ $5.52, \mathrm{~b}=0.84$ and $\mathrm{c}=-0.23$ for the exponential decrease in $\mathrm{pH}$ were obtained. The impala from the present investigation had a higher $\mathrm{pH}_{45}$ and a more rapid $\mathrm{pH}$ decline. Further investigations would be required to determine whether these differences are related to species or stress.

Most of the impala cropped were sighted and shot immediately. One of the male impala was wounded in the ear about 10 mins after first sighting and ran for 4 min before being killed. Of all the animals cropped, this individual was the most stressed. This observation was also supported by the post mortem $\mathrm{pH}$ profile $(\mathrm{a}=6.084 ; \mathrm{b}$ $=2.292 ; \mathrm{c}=-0.786$ ) where it was found that the animal not only had the highest $\mathrm{pH}_{\mathrm{f}}$ but also showed the fastest $\mathrm{pH}$ decline. This male impala also had the darkest meat $\left(\mathrm{L}^{*}=25.44 ; \mathrm{a}^{*}=9.13 ; \mathrm{b}^{*}=4.88\right)$. An abnormally high $\mathrm{pH}$ $(\mathrm{pH}>6.0)$ increases the light-absorption and water-binding abilities of postmortem muscle and results in an undesirable dark, firm and dry (DFD) cut surface. This specific impala ram did not lose any weight during the drip loss test period indicating that its muscle had a high water-binding capacity as a result of the high $\mathrm{pH}_{\mathrm{f}}$.

Veary (1991) analyzed the effects of three harvesting methods (helicopter, ground day and ground night) on the $\mathrm{pH}_{0}$ and $\mathrm{pH}_{48}$ values of the M. longissimus thoracis derived from the springbok (Antidorcas marsupialis). He 
noted $\mathrm{pH}_{0}$ values of $6.16,6.13,6.24$, respectively, in terms of cropping method and 5.67, 6.15 and 5.67, respectively, for $\mathrm{pH}_{48}$. The helicopter and night shooting $\mathrm{pH}_{48}$ values do not differ greatly from the $\mathrm{pH}_{\mathrm{f}}$ values of the present investigation on impala. Veary (1991) noted that the ground day harvesting proved the most stressful, a deduction not surprising as this method involves the skillful herding of the animals towards the shooting lines (where the marksmen are strategically placed in concealed / camouflaged places) using pick-up vehicles, scrambler motor-cycles or horsemen. The final $\mathrm{pH}$ values of the springbok harvested in the daytime were similar to that of the single impala ram that was stressed in this investigation. The nighttime harvesting employed in Veary's investigation was similar to that used in this study. The helicopter harvesting normally involves a two-seater helicopter with a pilot and marksman. The animals are shot from above (altitude of $6 \mathrm{~m}$ ) using a 12-bore shotgun aimed at the upper head and neck.

The various meat quality parameters measured showed no rifle calibre or sex effects $(\mathrm{P}>0.05$; Table 2$)$. Although the mean percentage drip loss was lower for males $(2.45 \%)$ than females $(2.6 \%)$, the value for males increased to $2.80 \%$ when the value of the stressed impala ram (0.0\% drip loss) was omitted. The drip losses noted for the impala (mean \% drip loss $=2.55 \pm 0.300$ ) are lower than that reported for beef animals (4-6\%) by Hornick et al. (1998), and similar to that reported for pigs (2.4-2.6\%) by Fisher et al. (2000). The cooking losses noted for the impala (Table 2) were similar (mean \% cooking loss $=23.98 \pm 0.367)$ to those reported for beef $(22-27 \%$ Hornick et al., 1998) and pork (27\% - Fisher et al., 2000) but lower than those of ostrich (32-33\% - Hoffman \& Fisher, unpublished observations). Venison is frequently perceived to be dry by consumers in South Africa. This perception could be due to the fact that most venison consumed originates from stressed animals that could be classified as DFD or because venison is known to have a low lipid content. Monro \& Skinner (1979) reported that the buttock fat of male impala ranged from 0.56 to $2.32 \%$. As noted by Issanchou (1996) and Kauffman (1993), intramuscular fat has a positive influence on the juiciness and flavour of meat. However, the perception that venison is tougher than other meat types does not correlate with the Warner Bratzler shear values noted in this investigation (mean value $=3.65 \pm 0.293 \mathrm{~kg} / 1.27 \mathrm{~cm}$ diameter). This value is similar to that reported for pigs (3 $\mathrm{kg} / 1.27 \mathrm{~cm}$ diameter - Fisher et al., 2000) and slightly lower than that of ostrich meat $(4-5 \mathrm{~kg} / 1.27 \mathrm{~cm}$ diameter Hoffman \& Fisher, unpublished observations). All these values are comparable, as they were determined in the same laboratory, utilizing the same equipment, methodology and conditions.

Venison sold in South African supermarkets is frequently dark brown (von La Chevallerie, 1972) and closely resembles the colour of ostrich meat. This dark colour may be caused by the animals being stressed during hunting with the result that the meat becomes dark, firm and dry (von La Chevallerie \& van Zyl, 1971; von La Chevallerie, 1972; Scanga et al., 1998). The Impala meat in this investigation was also darker and redder (mean values for $\mathrm{L}^{*}=$ $29.22 \pm 0.590, a^{*}=11.26 \pm 0.319$ and $\left.b^{*}=7.36 \pm 0.266\right)$ than that reported for pigs $\left(L^{*}=43.7, a^{*}=5.44, b^{*}=\right.$ 6.77) by Fisher et al. (2000). However, the impala muscle showed the same reflectance as young ostrich muscle $\left(\mathrm{L}^{*}=29.4\right)$ but was redder $\left(\mathrm{a}^{*}=11\right.$ vs 5$)$ than either young or older ostriches $\left(\mathrm{a}^{*}=9-\right.$ Hoffman \& Fisher, unpublished observations). A probable explanation for the darker muscle colour of venison (excluding that due to stress) is that these ungulates are more active and tend to run more than the traditionally farmed animals such as cattle and sheep. Lawrie (1998) notes that there is an elaboration of myoglobin during systematic exercise. The dark colour of the game meat may have a negative impact on consumers who prefer red meat that is neither extremely dark nor extremely pale (Jeremiah et al., 1972).

\section{Conclusions}

The results of this investigation show that the present method used for the cropping of impala, i.e. night shooting, does not have any detrimental effect on meat quality if the cropping activity does not alarm and stress the animals.

\section{Acknowledgements}

The help and facilities of the members of Maneze Wildlife Conservancy during the harvesting of the impala is greatly appreciated. The aid of M. Walters, K. de Graeff and J. van den Berg in the collection of the data is appreciated.

\section{References}

Commission International De L' Eclairage., 1976. Colorimetry, $2^{\text {nd }}$ Ed. CIE, Vienna.

Fisher, P., Mellett, F.D. \& Hoffman, L.C., 2000. Halothane genotype and pork quality. 1. Carcass and meat quality characteristics of three halothane genotypes. Meat Sci. 54, 97-105. 
Gill, C. \& Reichel, M., 1989. Growth of the cold-tolerant pathogens Yersinia enterocolitica, Aeromonas hydrophila and Listeria monocytogenus on high $\mathrm{pH}$ beef packaged under vacuum or carbon dioxide. Food Microbiol. 6, 223.

Gregory, N.G., 1996. Welfare and hygiene during preslaughter handling. Meat Sci. 43, S35-S46.

Hoffman, L.C., 2000. The yield and carcass chemical composition of impala (Aepyceros melampus), a southern African antelope species. J. Sci. Food \& Agric. 80, 752-756.

Hoffman, L.C. \& Ferreria, A.V., 2000. pH decline of the M. longissimus thoracis of night-cropped Grey Duiker (Sylvicapra grimmia). S. Afr. J. Anim. Sci. 30, 16-17.

Honikel, K.O., 1998. Reference methods for the assessment of physical characteristics of meat. Meat Sci. 49, 447457.

Hornick, J.L., Van Eenaeme, C., Clinquart, A., Diez, M. \& Istasse, L., 1998. Different periods of feed restriction before compensatory growth in Belgian Blue bulls: I. Animal performance, nitrogen balance, meat characteristics, and fat composition. J. Anim. Sci. 76, 249-259.

Issanchou, S., 1996. Consumer expectations of meat and meat product quality. Meat Sci. 43, S5-S19.

Jeremiah, L.E., Carpenter, Z.L. \& Smith, G.C. 1972. Beef color as related to consumer acceptance and palatability. J. Food Sci. 37, 476-479.

Kauffman, R.G., 1993. Opportunities for the meat industry in consumer satisfaction. Food Techn. 47, 132-134.

Lawrie, R.A., 1998. Lawrie's Meat Science. $6^{\text {th }}$ ed. Woodhead Publ. Ltd. Cambridge, England. 336p.

Lewis, A.R., Pinchin, A.M. \& Kestin, S.C., 1997. Welfare implications of the night shooting of wild Impala (Aepyceros melampus). Animal Welfare 6, 123-131.

Monro, R.H. \& Skinner, J.D., 1979. A note on condition indices for adult male impala, Aepyceros melampus. S. Afr. J. Anim. Sci. 9, 47-51.

SAS, 1988. SAS/STAT User's Guide, Release 6.03 ed. SAS Institute Inc., Cary, NC. 1028 p.

Scanga, J.A., Belk, K.E., Tatum, J.D., Grandin, T. \& Smith, G.C., 1998. Factors contributing to the incidence of dark cutting beef. J. Anim. Sci. 76, 2040-2047.

Veary, C.M., 1991. The effect of three slaughter methods and ambient temperature on the $\mathrm{pH}$ and temperatures in springbok (Antidorcus marsupialis) meat. MMedVet(Hyg) thesis. Faculty of Veterinary Science, University of Pretoria, South Africa.

Voisey, P.W., 1976. Engineering assessment and critique of instruments used for meat tenderness evaluation. J. Textural Studies 7, 11.

Von La Chevallerie M., 1972. Meat quality of seven wild ungulate species. S. Afr. J. Anim. Sci. 2, 101-103.

Von La Chevallerie, M. \& van Zyl, J.H.M., 1971. Some effects of shooting losses of meat and meat quality in springbok and impala. S. Afr. J. Anim. Sci. 1, 113-116. 